DOI: 10.2478/linpo-2014-0013

\title{
Cognate arguments and the Transitivity Requirement in the history of English ${ }^{1}$
}

\author{
Nikolaos Lavidas \\ Department of Theoretical and Applied Linguistics, School of English, \\ Aristotle University of Thessaloniki, nlavidas@enl.auth.gr
}

\begin{abstract}
Nikolaos Lavidas. Cognate arguments and the Transitivity Requirement in the history of English. The Poznań Society for the Advancement of the Arts and Sciences. PL ISSN 0079-4740, ISBN 978-83-7654-388-8, pp. 41-59

Starting with the Transitivity Requirement hypothesis [the direct object counterpart of Extended Projection Principle (EPP)], we examine the development of cognate objects and cognate subjects in English. We show that English extended the range of both cognate objects - which are now also possible with activity/event nouns - and cognate subjects - cognate subjects became an option for impersonal verbs. However, we argue that a correlation between the development of cognate arguments and the changes in null arguments should be excluded, whereas the development of the cognate arguments appears to be related to aspectual changes.
\end{abstract}

Keywords: cognate arguments, transitivity, English, diachronic syntax

\section{Introduction}

English extended the range of both cognate objects, which are now also possible with activity/event nouns (e.g., She smiled a smile of recognition), and cognate subjects, because cognate subjects became one - even though a less frequently used - option ${ }^{2}$ with impersonal (weather) verbs (e.g., The rain is raining all around; Stevenson, Robert Louis [1850-1894]. A Child's Garden of Verses and Underwoods). We will test the hypothesis that (a) cognate objects and cognate subjects follow parallel paths of development in English and (b) the rise of cognate objects with activity/event nouns is linked to the loss of referential null objects whereas the rise of cognate subjects is linked to the loss of null subjects in English.

This hypothesis has its basis in the Extended Projection Principle (EPP) - and its modifications according to the Minimalist Program (cf., for instance, Sigurðsson 2007, 2011) -

1 Parts of this study have been presented at ICEHL 17, SLE 45, and ISTAL 21. I thank the audience for the very valuable comments and suggestions provided. I also thank the anonymous reviewers for their remarks and relevant data, including cognate arguments in various stages of English. All errors remain mine.

2 The other (very often used) option is that of the expletive subject (It is raining all around). 
and its direct object counterpart principle, the Transitivity Requirement (TR) (Roberge 2002 and Cummins \& Roberge 2004, 2005). ${ }^{3}$ According to the EPP, a subject position is required in all cases - and can be covered with different mechanisms, for instance, through the verbal agreement; see, among others, Alexiadou \& Anagnostopoulou 1998. The TR claims that an object position is always present, even in the case of an intransitive verb.

Evidence for the TR is provided through the availability of cognate objects with unergative verbs (unergative verbs, according to other approaches, should not project an object position) and of null objects with transitive verbs. We will argue that cognate subjects - similar to verbal agreement in the case of null subjects - can be treated as evidence in favor of the Subject Position Requirement or EPP (contrary to Roberge 2002 and Cummins \& Roberge 2004, 2005; see below).

Previous historical studies of activity/event-noun ('aspectual') cognate objects mainly include Horrocks \& Stavrou's (2010) study that examined why only some languages have 'aspectual' cognate objects - and why these cognate objects are disallowed in other languages - and the differences among Modern English ('aspectual' cognate objects are available) and Ancient and Modern Greek ('aspectual' cognate objects are disallowed). For Horrocks \& Stavrou, the availability of 'aspectual' cognate objects should be linked to the presence of telicity-shifting constructions in a language (cf. Horrocks \& Stavrou 2003, 2007); such shifts correlate with whether a language has a grammaticalized viewpoint aspect in verbal stems (see below). ${ }^{4}$

Accordingly, we will test the hypotheses (using empirical evidence) that: (i) The development/rise of cognate objects can parallel the development/rise of overt (instead of null) referential objects and, consequently, the development of aspect (if aspect can be considered as the crucial parameter that allows/disallows null objects); (ii) The development/rise of cognate subjects can parallel the development of overt (instead of null) subjects and, consequently, the development of verbal agreement (if agreement can be considered as the significant parameter that allows/disallows null subjects); (iii) Cognate objects and subjects are linked to changes in the aspectual system of English, and the additional empirical evidence is in favor of Horrocks and Stavrou's analysis.

In the following section, we discuss the TR hypothesis and a version of the EPP hypothesis according to the Minimalism Program, and we present the research questions that derive (regarding the diachrony of English) from these hypotheses. In section 3.1, we describe the chronology of the development of cognate objects and subjects in English to examine the parameters that determine the changes in these phenomena and the possibility of a parallel development. In section 3.2, we show that the changes in null arguments are in the opposite direction of the development of cognate arguments (loss of null expletive subjects and null referential objects vs. use [and productivity] of cognate expletive subjects and overt referential objects), and that the cognate arguments cannot be analyzed as a replacement mechanism for null arguments. In section 3.3, we propose an alternative hypothesis, according to which both cognate objects and subjects are linked to changes in the aspectual system of English; this hypothesis can be valid if cognate nouns are used to check aspectual features (2004)

See also Basilico (1998), Pirvulescu \& Roberge (1999), Bowers (2002), and Erteschik-Shir \& Rapoport

4 On the relation between objects (in general - not cognate arguments) and aspect, cf. Tenny $(1987,1994)$, Borer (1994), Travis (1994), Massam (1990), Roberge (2002), and below. 
- see Roberge (2002), Cummins \& Roberge (2004, 2005), and Horrocks \& Stavrou (2010), among others. In section 4 , we conclude the main findings and remarks of this study. ${ }^{5}$

\section{Background: TR, cognate and null arguments}

Roberge (2002) and Cummins \& Roberge $(2004,2005)$ have argued that null and implicit objects can be attributed to the TR, just as null subjects (empty categories in subject position, pro) are due to the EPP. According to the TR hypothesis (see 1), the object position is always syntactically present in a similar way as the subject position.

Transitivity Requirement: "An Obj position is always included in VP, independently of lexical choice of V. TR is the internal argument counterpart to the EPP” (Roberge 2002; Cummins \& Roberge 2004, 2005).

On the other hand, for Roberge (2002) and Cummins \& Roberge $(2004,2005)$, the contrast between the presence of cognate objects (ex. 2a, b) and the near absence (but see below) of cognate subjects ("While cognate objects are widespread, cognate subjects seem conspicuously non-existent" [Roberge 2002]) is another evidence in favor of an obligatory object position; according to this view, cognate objects are present with unergative verbs even though cognate subjects are almost unavailable - the reason is that cognate objects are the only option for the object position in case of an unergative verb.

(2) a. Mary smiled a funny smile at me.

b. They will sing popular songs to each other.

For Roberge (2002) and Cummins \& Roberge $(2004,2005)$, to say that there is a cognate subject, we need a nonexpletive subject in an external argument position with an impersonal verb. Cummins \& Roberge conclude that even though there is a subject position, impersonal verbs do not provide the necessary content to allow the presence of an external argument; on the other hand, an object position is also given by the syntax and can be filled with cognate objects according to the interpretation of the verb and the object. Thus, Cummins \& Roberge find differences between null subjects and objects: "The recoverability of null subjects is morphologically driven. In most cases, the recoverability of null objects is semantically driven." (Roberge 2002). ${ }^{6}$ The direct object position is given by the syntax and can be filled with (a regular object or) an empty or a cognate object depending on the verbal meaning.

The EPP has been "translated" according to Minimalist Program by, among others, Frascarelli \& Hinterhölzl (2007) and Sigurðsson (2007, 2011). Sigurðsson has developed a theory of C/edge linking in terms of syntactically present but silent $\mathrm{C}$-features; all (overt and silent) referential arguments must match $\mathrm{C}$-features to be successfully C/edge-linked and interpreted. Accordingly, Sigurðsson has distinguished three types of null subjects:

5 The main research question (and probable contribution) of this study is to test using empirical historical data some hypotheses (see above) that emerge as a sort of synergy from the connection in a new way of findings reached by other researches.

6 Hence, transitives without objects do not become unergatives because, according to the TR hypothesis, they always have a direct object position, which can take an empty element. 
(a) Germanic null subjects with topic-drop (with topics requiring an empty [Spec, CP]),

(b) Romance null subjects with pro-drop (where agreement incorporates a pronoun), and

(c) Chinese null subjects with discourse-drop (with linking to C-edge by long distance).

In the following section, we describe the changes in cognate arguments in the history of English (3.1) and the relation these may have with the diachrony of null arguments (3.2) or Aspect (3.3).

\section{Cognate arguments in the diachrony of English}

\subsection{Cognate objects vs. cognate subjects}

Cognate objects can be:

(a) regular objects with typical transitive verbs, have concrete meanings, be any type of DP (singular or plural, for instance), and freely be passivized (ex. 3);

(b) "transitivizing" objects with unergative verbs (ex. 4); the passivization of cognate objects with unergative verbs is not common;

(c) "activity/event-noun" or "aspectual" cognate objects; "aspectual" objects are nonreferential arguments (ex. 5a-e); cf. Jones (1988), Massam (1990), Macfarland (1995), Mittwoch (1998), Pereltsvaig (1999), and Horrocks \& Stavrou (2010).

She ended the class by asking us to write a writing under given time.

(5) a. ??A (winning) smile was smiled by the winner.

b. $\quad * A$ (winning) smile, no one smiled.

c. *What did she smile?

d. ?She smiled (all the, some ...) smiles.

e. $\quad$ She smiled a (winning) smile (*a grin).

(Horrocks \& Stavrou 2010)

For a detailed analysis of the characteristics of "aspectual" cognate objects, see Horrocks \& Stavrou (2010: 303):

Following Tenny 1994, Levin and Rappaport Hovav 1995, Macfarland 1995, we take the last of these [=the interpretation of terminative processes/events] to be the one involved in the 'core' $\mathrm{C}$ [ognate]O[object]C[onstruction]s of English. The parallels between event-noun COCs [grin a grin] and 'true' LVCs [light-verb constructions] [...] like Sarah gave (us) a cheesy grin, whose objects are similarly defective, are striking [...] Whereas the lexical aspectual character of the vast majority of unergatives like [to] grin is non-terminative, i.e. they denote open-ended activities, the corresponding deverbal event nouns like [a] grin are most naturally understood, in the absence of strong contextual cues to the contrary (e.g. a durative adverbial), to denote inherently limited events with beginnings and ends, as in she gave us a grin, etc. This property characterises the relevant LVCs, and it is the change of default aspectual character vis-à-vis the simple verb that gives the construction its principal raison d'être.

Visser (1963 [2002]: 415) has argued that the "activity/event-nouns" cognate objects - in contrast to the other types of cognate objects - are a recent development in English, were rare in Old English but had increasing frequency in Middle English and Early Modern English (ex. 6), and are frequent in Modern English (see also the results from a corpus study below); see Table 1. 


$$
\begin{aligned}
& \text { Ere the Bat hath flowne His Cloyster'd flight. } \\
& \text { before the bat has flown his cloistered flight } \\
& \text { 'Before the bat flies his cloistered flight.' } \\
& \text { (Shakesp., Macb. III, ii, 40; from Visser (1963 [2002]: 417) }
\end{aligned}
$$

Table 1: Cognate objects in Old English and Modern English

\begin{tabular}{lccc}
\hline & $\begin{array}{c}\text { Typical transitive } \\
\text { cognate objects }\end{array}$ & $\begin{array}{c}\text { Transitivizing cognate } \\
\text { objects }\end{array}$ & $\begin{array}{c}\text { "Aspectual” cognate } \\
\text { objects }\end{array}$ \\
\hline Old English & $\sqrt{ }$ & $\sqrt{ }$ & $*$ \\
Modern English & $\sqrt{ }$ & $\sqrt{ }$ & $\sqrt{ }$ \\
\hline
\end{tabular}

In order to test Visser's remarks, ${ }^{7}$ we have collected 59 verbs that could take a cognate object in a particular period of the English language and for which there is a clear description (or example) of the first appearance of their cognate object construction in the online version of the Oxford English Dictionary (OED) (see Table 2 and ex. 7a-d). ${ }^{8}$ Furthermore, we have searched for these 59 cognate object constructions in the York-Toronto-Helsinki Parsed Corpus of Old English Prose (YCOE), the Penn-Helsinki Parsed Corpus of Middle English (PPCME2), the Penn-Helsinki Parsed Corpus of Early Modern English (PPCEME), and the Penn-Helsinki Parsed Corpus of Modern British English (PPCMBE) (Kroch \& Taylor 2000; Taylor et al. 2003; Kroch et al. 2004, 2010). This search yielded no significant results for most of the cognate object constructions; because there are not many examples of these cognate object constructions in the specific electronic corpora, the frequency of their appearance in the corpora cannot be tested statistically. Table 3 presents the frequency of appearance in the electronic historical corpora of the "die + death" cognate object construction per 10k clauses (for more details, see also Lavidas 2013b). ${ }^{9}$ What we would like to test here - following Visser's remarks - is the period in which these cognate object constructions first appear and the period (if any) in which they become more frequent and common. Of course, this corpora study and statistical analysis depend on lexical characteristics, and, for this reason, the search can be affected by the differences in the corpora size and the registers. ${ }^{10}$ Therefore, we cannot conclude to generalizations on the basis of these tables, but only

7 Of course, Visser does not present any quantitative study but remarks on examples from texts of the relevant periods. Therefore, it is valuable to test these remarks against electronic historical corpora (which, of course, were not available in the time of Visser).

8 Due to space limitations, only a part of the conducted corpora analyses - the part that is related to the contrast between cognate objects and subjects - will be presented here. For more on the analysis of the historical presence of cognate objects and on cross-linguistic remarks, see Lavidas (2013b).

9 We have decided to use this particular cognate construction (die death) because this construction is much more frequent and present in many periods in the corpora in contrast to the other constructions (for which information about their first appearance is also found in the OED). Hence, our choice to use this cognate construction is not a result of some features of the specific verb and cognate object. Unfortunately for our research, the verb with the most frequent use with a cognate noun in all periods is an unaccusative one. But see Larson (1988: 386-387) and Macfarland (1995) for a different opinion; for them, the verb die is unergative. We believe that, even if this verb is unaccusative in all periods, the remarks on the rise of the cognate construction with this verb can be indicative for the development of cognate constructions as a more general phenomenon and its relation to transitivity.

${ }^{10}$ An alternative hypothesis for a structural independent change would be that a change is reflected in the data that is part information-structural and part due to the rise of stylistic conventions for writing. This change can be linked to the movement of English toward a strict SVO order in Early Modern English. In Early Modern 
on the basis of the chronology of first appearances (for example, we will not examine the slope and intercept parameters - see below).

Table 2: Number of cognate constructions that first appeared in each period (according to a search in the etymological information included in the online OED) $)^{11,12}$

\begin{tabular}{cccccccccccc}
\hline Periods & O2 & O3 & O4 & M1 & M2 & M3 & M4 & E1 & E2 & E3 & MBE \\
\hline New & 0 & 0 & $3 / 59$ & 0 & $7 / 59$ & $8 / 59$ & $6 / 59$ & $1 / 59$ & $7 / 59$ & $8 / 59$ & $19 / 59$ \\
$\begin{array}{c}\text { Cognate } \\
\begin{array}{c}\text { Constru- } \\
\text { ctions }\end{array}\end{array}$ & & $(5.08 \%)$ & & $(11.86 \%)$ & $(13.56 \%)$ & $(10.17 \%)$ & $(1.69 \%)$ & $(11.86 \%)$ & $(13.56 \%)$ & $(32.20 \%)$ \\
\hline
\end{tabular}

Table 3: "die + death" cognate object construction in the electronic historical corpora (Max/10k)

\begin{tabular}{cccccccccccc}
\hline Periods & O2 & O3 & O4 & M1 & M2 & M3 & M4 & E1 & E2 & E3 & MBE \\
\hline $\begin{array}{c}\text { die + death, } \\
\text { Max/10k }\end{array}$ & 0 & 0 & 0 & 0 & 0 & 0.61 & 1.03 & 0.59 & 0.71 & 0 & 0.5 \\
\hline
\end{tabular}

(7) a. Efter pire wordis A lowde lazter he loze.

(Wars Alexander (Ashm.) (1989) 1. 96; c1450 (1400))

b. The gaunt hobbledehoy grinning a very unlovely grin.

(G. A. Sala Journey due South (1887) i. xxvi. 356; 1884)

c. Mr. Weller junior smiled a filial smile.

(Dickens Pickwick Papers (1837) xxiii. 238; 1836)

English, syntactic function maps onto information-structural status (subjects are given information and objects are new information). In Old English, however, the many possible unmarked positions for subjects and objects did not enforce such mapping; for example, new subjects could be positioned unproblematically after the finite verb because of the V2 constraint (Los \& van Kemenade 2012). Furthermore, end-weight becomes more prominent in English and - in at least the written language - a tendency emerges to end clauses with DPs (1b, 2b) rather than with verbs (or adjectives) (1a, 2a):

(1) a. Sebastian appeared. >

b. Sebastian made an appearance.

(2) a. Maintenance is important. >

b. Maintenance is an important issue. (Aarts 1995; Allerton 2002)

Accordingly, most examples of cognate objects are modified (with a premodifying adjective: flown his cloyster'd flight; grinning a very unlovely grin; smiled a filial smile) or with a postmodifying relative clause (vote a vote untampered with by one wise man). It seems that the new information of the clause is encoded in the modification. The issue remains open for further research.

${ }_{11}$ The chronological periods (according to the York, Helsinki, and Pennsylvania corpora) in all figures and tables are the following: O2 (Old English; 850-950); O3 (Old English; 950-1050); O4 (Old English; 1050-1150); M1 (Middle English; 1150-1250); M2 (Middle English; 1250-1350); M3 (Middle English; 1350-1420); M4 (Middle English; 1420-1500); E1 (Early Modern English; 1500-1569); E2 (Early Modern English; 1570-1639); E3 (Early Modern English; 1640-1710); MBE (Modern British English; 1700-1914).

12 The Dictionary of Old English (DOE) and the Middle English Dictionary (MED) also provide us with examples of cognate objects in Old and Middle English. I thank the anonymous reviewer for this observation. E.g.:

(1) a. \& hit drinco drenc eadiges blodes. (HyGl 3, 127.3)

b. and him gife geafon. (ÆCHom II, 35, 267.217)

c. She..slepte hir firste sleep and awook. (Chaucer CT.Sq.(Manly-Rickert), F.367; c1395) 
d. And divers hundred thousand fools may vote a vote untampered with by one wise man. (R. Browning Prince Hohenstiel-Schwangau 65; 1871)

Visser's observations (that cognate object constructions are common during the Middle English period [after 1250]) are confirmed by the corpora search results. A Pearson chisquare test was performed to assess the relationship between the different periods of the history of the English language and the development of cognate object constructions. The results with respect to the new cognate object constructions were statistically significant for most of the periods and, mainly, for the following comparisons: (a) between M1 and M2 $\left(\chi^{2}=12.61, p<.001\right)$, with an effect size of $\varphi=.25$, which is a medium size effect, and (b) between E1 and E2 $\left(\chi^{2}=8.19, p=.004\right)$, with an effect size of $\varphi=.20$, which is a small size effect. The results with respect to the "die + death" cognate object construction were statistically significant for the comparisons (a) between M2 and M3 ( $\left.\chi^{2}=6.02, p=.01\right)$, with an effect size of $\varphi=.06$, which is a small size effect, and (b) between E2 and E3 $\left(\chi^{2}=7.06, p=\right.$ $.01)$, with an effect size of $\varphi=.06$, which is a small size effect.

It is obvious that the situation is not the same with cognate subjects, which are not so common even in Modern English (see above). This is why not many Modern English grammars or studies mention cognate subjects:

Quirk et al. (1985: 750):

"[cognate subjects are the case] in which it is the meaning of the subject that is presupposed by the verb"

Langacker (1991: 366):

"[cognate subjects are the case] in which the subject and the verb redundantly convey the same conceptual content"

Höche (2009) has commented on this gap in the analysis of cognate subjects in Modern English, and has collected relevant examples with cognate subjects (and objects) from the relevant literature and from authentic data:

(10) a. $\quad$ Rain rains. (Langacker 1991a: 366)

b. Still the thunder thundered and burned and shook them. (CJA: 2036)

c. [...] and the winds blew and the hail hailed and the rains poured down causing floods.

(community2.webtv.net/pantheralex/LATESTNEWSV/page2.html)

d. The frost froze hard. (Quirk et al. 1985: 750) ${ }^{13}$

It's raining rain from the skies, and it's raining real tears from my eyes.

(Höche 2009: 90)

Höche's examples are extremely useful because they reveal the availability of the presence of cognate subject and object with one specific verb, the verb rain (see our corpus study below). In general, weather verbs appear to be the best examples for cognate subjects

13 This example may not present an unergative verb with an underived subject. The verb "freeze" can form a causative/anticausative alternation (She froze the fish - The fish froze) and example (10d) is actually a resultative construction that has been used as a test of unaccusativity. Hence, in example (10d), we may have a case of a derived cognate subject. 
(see Denison 1993). The same has been shown in Zaefferer's (2002) study. Zaefferer has demonstrated that the verb rain cross-linguistically can have cognate arguments. Again, Zaefferer's examples show that in Modern English rain is able to take both a cognate object and a cognate subject and that the argument with rain can denote either the prototypical rain meaning or a metaphorical meaning.

\section{It is raining a hard rain.}

\section{The rain is raining.}

It rained confetti as the Big Apple prepared for the big night.

... where confetti rained at the end of the game.

(Zaefferer 2002: 427)

The cognate subject can be used instead of the expletive it in Modern English in the case of weather verbs (it is raining; the rain is raining - see below for more examples from COHA). In Early English, the expletive it was not obligatory, and our search in the electronic historical corpora has shown that neither the cognate subject was a common option at all. It seems that when the null subject was a grammatical option, the cognate subject was not available to be used with weather verbs. One can claim that perhaps there is a relationship between the development of null subjects (their loss) and the development of cognate subjects (their rise, for instance with weather verbs). Even though this hypothesis seems possible, we will see in the following section that the chronology of these changes is absolutely unrelated. Moreover, according to an anonymous reviewer, a study of the material included in the Dictionary of Old English (DOE) and the Middle English Dictionary (MED) would also support the lack of any relation between the emergence of the cognate subjects and the loss of null subjects: cognate subjects are attested even in Old and Middle English. ${ }^{14}$

An analogous historical search for cognate subjects (to the one for cognate objects) is not easy at all - which confirms Cummins \& Roberge's remarks [see above] on the contrast between cognate objects and cognate subjects. We conducted corpora searches using the same electronic historical corpora and PCEEC (Corpus of Early English Correspondence) for Old English and the weather verb 'rain' in all of the various types and spellings with which it has appeared in different periods of the history of the English language. ${ }^{15}$ The results show that cognate subjects with impersonal verbs are more productive in Modern English; indeed, there are zero examples in the Old, Middle, and Early Modern English corpora we have examined. Due to this fact, we have decided to present the results from another

14 The anonymous reviewer's observations add a significant argument in favor of the dissociation between the development of cognate subjects and the development of null subjects. See the examples below from the Dictionary of Old English (DOE) and the Middle English Dictionary (MED):

(1) a. Whon pe Forst fresep, foode hem [birds] bi-houep. (PPI.A(1) (Vrn) 8.115; c1390)

b. $\quad$ Dis rain rained euer on-ane. (Cursor (Göt Theol 107) 1835; a1400)

c. The reyne pat reyneth pere we reste sholde, Ben sikenesses \& sorwes.

(PP1.B (LdMisc 581) 17.333; c1400 (c1378))

d. Heuene was yclosed, That no reyne reynede (PPl.C (Hnt HM 137) 16.270; c1400(?a1387))

15 According to the OED:

rain (noun): OE hrcegn, hren, ragn, regen, reng (rare), regn, ME ran, reigne, reine, rene, reygne, reynne, rien, 17 th century rain.

rain (verb): OE hregnia (Northumbrian), regnian (Mercian), ME raynn, regne, reigne, reine, reyghn, reygne, reyn, 16th century raign, reign, 17 th century rain. 
corpora, the Corpus of Historical American English (COHA, 1810-2009; http://corpus2. byu.edu/coha). The results from COHA are not numerous but they come in contrast to the absence of examples for the verb 'rain' with a cognate subject in the Old, Middle, and Early Modern English electronic corpora: ${ }^{16}$

COHA, 19th century

Cognate subjects: five examples ${ }^{17}$

1841 If only that the sun shines and the rain rains for both.

1861 Lady Christina Blest is the corse the rain rains on.

1863 And blessed is the corpse that the rain rains on.

1885 Ah, many's the time, at sea, when the rain rained, and the wind blew, and the snow snew.

1883 If only that the sun shines and the rain rains for both.

COHA, 1900-1950

Cognate subjects: seven examples ${ }^{18}$

1900 Rain had never rained so hard, he thought.

1909 That girl was what the sun shone for an' the rain rained for an' the blossoms blossomed for.

1908 The rain was still raining, and there was heavy clouds in the northwest.

1913 Where the rain might rain upon them.

1931 And the sun was shining or the rain raining on the less exalted business of every day.

1933 The sun shines? the rain rains? the ice cracks and creeps?

1940 The sun shines? the rain rains?

COHA, 1950-2009

Cognate subjects: four examples ${ }^{19}$

1959 The rain rained down on the illuminated scene.

1959 The rain was still raining, the wind was still blowing.

16 There are several different views with regard to the COHA studies and the doubles that may occur in the data because of the multiple editions of the same work in the data. We have to note that our study here is not a quantitative (it could not be a quantitative with so few examples found; we mention all examples without any exception). Therefore, it is not affected by the multiple editions at all.

17 And only one example of cognate object:

1859 Some men are always opening the windows of heaven, raining a rain of mercy.

18 There are four cognate object examples with the same verb:

1917 It rained an icy rain at the river-side, and Squaw Peak was covered white with snow.

1914 It may rain today, but it won't rain rain.

1920 It is not raining rain to me.

1920 It is not raining rain to me.

19 And four examples of cognate objects:

1953 It doesn 't rain rain any more, it rains soapsuds.

1976 It rained tropical rains there.

1972 It was so cold that it wasn't raining rain.

1977 She had a cloud raining this slanted blue rain onto a little stick figure girl with an umbrella. 
1979 After mid-month the rain rained lightly.

1997 The rain still rains, the hats still keep it out.

In the next section, we will test whether there is a relationship between the diachrony of cognate arguments and the development of null arguments, again following the approach of EPP and TR.

\subsection{Is there any relation between the development of cognate arguments and the changes in null arguments?}

Null objects can have either (a) a specific referent that was introduced in the previous discourse ("referential null objects") or (b) an indefinite (or no) antecedent present in the discourse ("nonreferential null objects"). ${ }^{20}$ Modern English disallows referential null objects (ex. 16), whereas not all native speakers accept nonreferential null objects (ex. 17). Only the subtype of generic (modal) nonreferential null objects is available in Modern English without restrictions or disagreement among scholars or native speakers (ex. 18). According to the relevant literature, however, this subtype of nonreferential null objects appears to be available in all languages and historical periods.

Referential null object

$$
\text { -Did you bring your yellow hat? }{ }^{21}
$$$$
-I \text { brought } *(\underline{\boldsymbol{i}}) \text {. }
$$

Nonreferential null object

$$
\text { The presidential debate started. */?The candidates argued and interrupted } \underline{\boldsymbol{\emptyset}} \text {. }
$$

Generic nonreferential null object

They have the ability to create and change $\underline{\underline{\boldsymbol{O}}}$.

On the other hand, Old English allows referential null objects (see ex. 19 and 20, and Table 4). According to Visser (1963 [2002]: 525), referential null objects are available in Old and Middle English but are rare in the 16th century and disappear subsequently (see also the results of a corpus study below). ${ }^{22}$ For instance, example (20) demonstrates non-repetition of the object in Old English in cases in which Modern English must use a pronoun (ex. 21):

$$
\begin{aligned}
& \text { He nam hlaf and } \underline{\varnothing} \text { heold betweox his handum. } \\
& \text { he:NOM took:3sG loaf:ACC and } \varnothing \text { held:3sG between his hands } \\
& \text { 'He took the loaf and held [it] between his hands.' (Wulfstan, Polity (Jost) p. } 228 \\
& \text { par.117; from Visser (1963 [2002]: 525)) }
\end{aligned}
$$

20 Cf. Huang 1984; Lambrecht \& Lemoine 1996; Giannakidou \& Merchant 1997; Larjavaara 2000; García Velasco \& Portero Muñoz 2002; Panagiotidis 2003; Cummins \& Roberge 2004, 2005, and Tsimpli \& Papadopoulou 2006.

21 We mark the antecedent in bold.

22 Please note that Visser neither states the hypothesis of a relation between cognate and null arguments nor compares cognate and null objects or provides a quantitative analysis of such data. Visser provides some remarks on the availability of null objects in early English and on the nonavailability of cognate objects in early English (in different sections of his book). Furthermore, in the previous literature, neither Visser nor other scholars examined the correlation between cognate subjects and null subjects. 


$\begin{array}{lllll}\begin{array}{l}\text { Nympe } \\ \text { unless }\end{array} & \text { liges foepm } \\ \text { flasp:Nom }\end{array} \quad \underline{\varnothing} \begin{aligned} & \text { swulge } \\ & \text { engulfed:3sg in smoke }\end{aligned}$

'[So well had weened the wisest Scyldings that not ever at all might any man that bone-decked, brave house break asunder, crush by craft,] unless clasp of fire in smoke engulfed [it]' ${ }^{23}$ (Beowulf 781-782; cf. Visser (1963 [2002]: 528))

\begin{tabular}{|c|c|c|}
\hline & Referential null objects & Nonreferential null objects \\
\hline Old English & $\sqrt{ }$ & $\sqrt{ }$ \\
\hline Modern English & $*$ & $? / *$ \\
\hline
\end{tabular}

In Figures $1 \mathrm{a}$ and $1 \mathrm{~b}$, we present the results of a corpus study regarding the presence of overt direct objects (DPs and only pronouns, respectively) in different periods..$^{24}$ If Visser is correct and there is a tendency for loss of the null objects, this tendency should be apparent in the historical corpora. We have searched for changes in the presence of verbs that take a DP-complement (Figure 1a) or an object pronoun (Figure 1b) (in the genitive, dative, or accusative case) in YCOE, PPCME2, PPCEME, and PPCMBE. The electronic historical corpora include no coding for null objects; therefore, we decided to search for all clauses that contain a verb (non-auxiliary in main or subordinated clauses) and a direct object and to compare them with all clauses that contain a verb but no direct object. ${ }^{25}$

The corpora study confirms Visser's observations that there is a tendency for loss of the null objects in Middle and Early Modern English. Furthermore, another aspect of the development of overt and null direct objects is evident in the results. The main change in null and overt direct objects appears to take place from the end of the Old English period to the beginning of the Middle English period. A Pearson chi-square test was performed to assess the relationship between the development of overt objects and the different periods. The results were statistically significant for the comparison between $\mathrm{O} 4$ and M1 $\left(\chi^{2}=35.46\right.$, $p<.001$ ), with an effect size of $\varphi=.42$, which is a large size effect (for Figure 1a).

On the other hand, our initial hypothesis - following Visser - that both the loss of referential null objects and the rise of cognate objects occurred during the same period is not absolutely confirmed. As we have observed in section 3.1, the changes in cognate objects

${ }^{23}$ See Gummere (1910).

${ }^{24}$ The data of object pronouns reveal exactly the same tendency as the data with the direct objects (nouns or pronouns). This fact can make us exclude an alternative hypothesis that the tendency observed in both figures is a result of the change in characteristics of pronouns or nouns alone. Since it appears in both figures, we cannot say, for example, that the tendency observed is the result of the replacement of the paratactic correlative structures by hypotactic embedded structures. A pattern like I wish that, that [clause] is faded out, and I wish that [clause] becomes the regular pattern; actually, this replacement is in the opposite direction than the general change in overt objects, because the pronoun is less (and not more) productive than in the past with these constructions. Furthermore, the correlative cataphoric pronoun can affect the results of the figure with the pronouns but not the results of the figures with the DPs-objects.

${ }^{25}$ Due to space limitations, only a part of the conducted corpora analyses will be presented here. For more on the development of null objects, see Lavidas (2013b). 


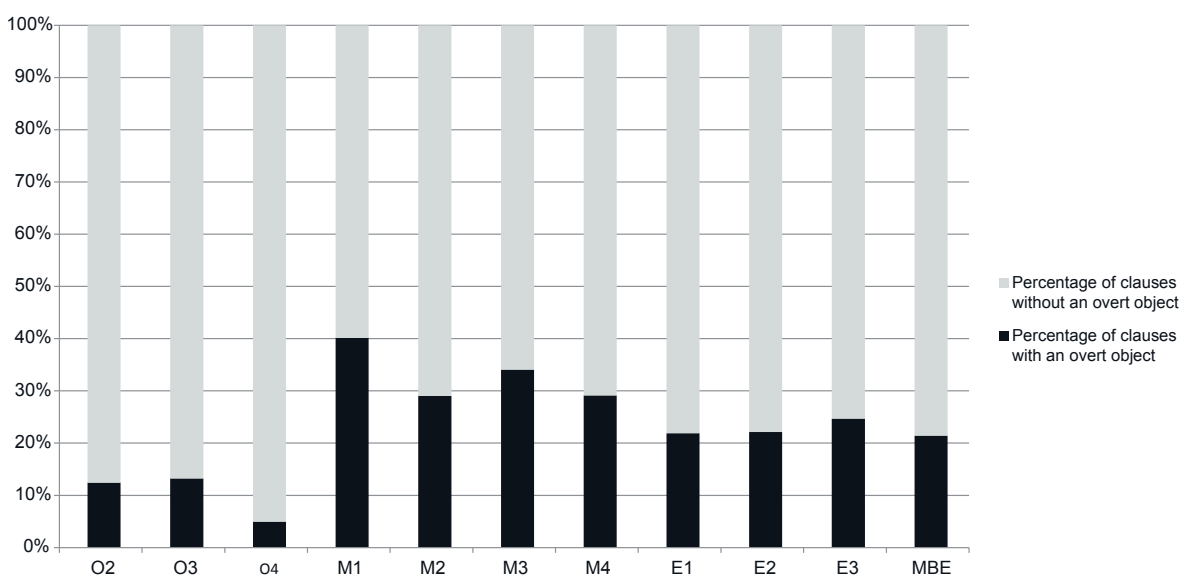

Figure 1a: The development of overt direct objects (see also Lavidas 2013b) ${ }^{26}$

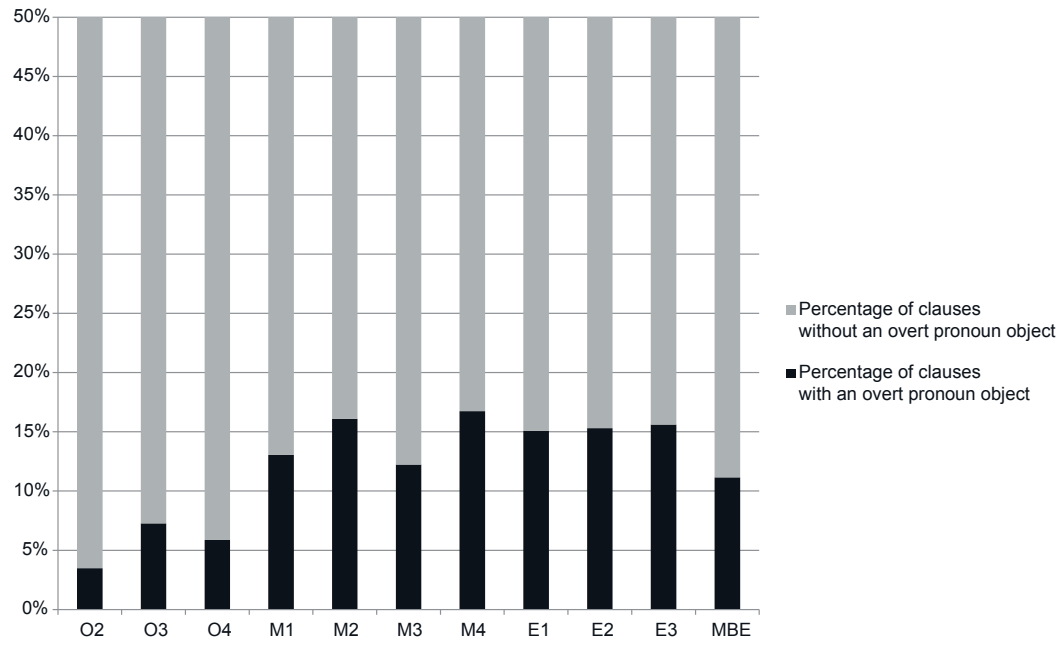

Figure 1b: The development of overt pronoun objects

involve the period from the 13th century and not the transition from the Old English to the Middle English period. It is clear that the development of cognate objects is not similar to the development of overt and null objects, and that null and cognate objects are most likely linked to different phenomena (see also Lavidas 2013b).

A correlation between cognate subjects and null subjects is a legitimate hypothesis (see also our relevant remarks above) since null subjects are allowed in Early English when cognate subjects were not productive. ${ }^{27}$ Van Gelderen (2000a, b, 2010) has argued that the null

26 In the corpus studies presented in this article, we do not consider any other type of variation between the periods represented because the data are discussed in terms of the frequency at which the phenomena (for instance, verbs with overt direct objects) occur vs. those cases in which the syntactic alternatives (for instance, verbs with null objects) occur - following, among many others, Kroch (1989) and Pintzuk (2002).

27 For a detailed study of null arguments in Old English, see also Walkden (2011). 
subjects are available in Old English, are typically controlled by Familiar or Given Topics (unlike Italian and Germanic null subjects - see also above on Sigurðsson's analysis (2007, 2011)), and that in some cases there is agreement licensing. See examples (22) and (23). ${ }^{28,29}$

\section{Nap nihtscua, norpan sniwde}

darkened night-shadow north-from snowed

'The shadow of the night darkened, it snowed from the North.'

(Exeter, Seafarer 31) from van Gelderen (2010)
Nu scylun hergan hefaenricaes uard
now must praise heavenly-kingdom guard
'Now we must praise the lord of the heavenly kingdom.'
(Northumbrian version of Caedmon's Hymn) from van Gelderen (2010)

For our discussion of cognate subjects with weather verbs (because weather verbs are the verbs that can be found with a cognate subject - see above), the characteristics and development of the expletive $(h) i t$ are significant, if we want to test the hypothesis of a relationship between the rise of the expletive $(h) i t$ and the rise of the cognate subject with weather verbs. According to Visser (1963 [2002]: 36ff.), (h)it can appear with weather verbs in Early English (and verbs of time of day or season of year; space, distance): freosan 'freeze', hagolian 'hail', lihtan 'lighten', rinan 'rain', sniwan 'snow', pawian 'thaw' (see ex. 24).

\section{Hit rine and sniwe and styrme ute}

'It rains and snows and storms come.'

(Ælfred, Bede 2, 13, Visser (1963 [2002]: 37)

Visser also has shown that weather verbs can be found with a null subject in Old English (see ex. 25) as well as several cases in which a weather verb is used with a null subject in Old English but with (h)it in Middle English (for instance, it sleteth 'it is sleeting' with an overt subject around 1340).

\section{Norpan sniwde \\ north-from snowed}

'Snow fell from the north' (Exeter, Seafarer 31, Visser (1963 [2002]: 36))

Following Williams' (2000) data and analysis of the chronology of null subjects in English existentials, we consider that after 1250 null expletives decrease radically and that there is a significant distance between the loss of null expletives (circa 1250) and the rise of use of cognate subjects (see our discussion in 3.2). With regard to the chronology of null subjects and their loss (to provide only few details since the chronological distance between the loss of null expletive subjects and the rise of cognate expletive subjects is large), in Old English

28 Van Gelderen does not link null subjects to cognate subjects and, therefore, the explanation of the development of the null subjects cannot be directly applied to the development of the cognate subjects.

${ }^{29}$ Furthermore, van Gelderen (2000a, b, 2004, 2010) has shown that in Early Middle English, when pro-drop is lost, the pronominal system of English changes (for instance, h-pronouns take over some of the functions of demonstratives). Van Gelderen's explanation of this change in the pronominal system of English includes a major reanalysis of the agreement features from interpretable to uninterpretable, a change of personal pronouns into deictic/ referential, and a reanalysis of the CP-layer that no longer has familiar topics licensing subordinate null subjects. 
and Early Middle English (1150-1250), the expletives (h)it and there can be missing (for instance, with weather verbs). After 1250 , null expletives are very rare and can be found only with very few constructions or verbs (cf. Williams 2000). Williams has shown (on the basis of a corpus study using 52 Middle English texts from the first edition of the Penn-Helsinki corpora - see Table 5) that in Early Middle English null expletives are still allowed but there is a dramatic decrease in their frequency after 1250 .

Table 5: Existentials with vs. without expletive there (Williams 2000: 169)

\begin{tabular}{lccc}
\hline Period & Existentials with there & $\begin{array}{c}\text { Existentials without } \\
\text { there }\end{array}$ & $\begin{array}{c}\text { Existentials without } \\
\text { there } \\
\%\end{array}$ \\
\hline $1150-1250$ & 28 & 70 & 71 \\
$1250-1350$ & 41 & 7 & 15 \\
$1350-1420$ & 179 & 60 & 25 \\
$1420-1500$ & 154 & 32 & 17 \\
\hline
\end{tabular}

It is therefore evident that neither a historical correlation between cognate arguments and null arguments can be supported by the data of their development.

\subsection{An alternative hypothesis: cognate arguments and aspect}

Following the relevant literature (among others, Tenny (1987, 1994), Borer (1994), Travis (1994) - and Massam (1990) and Horrocks \& Stavrou (2010) for cognate objects; see above Section 3.1), we assume that cognate arguments and Aspect are related (see 26 and 27 below). The observed changes in cognate arguments (especially in cognate objects - see also Lavidas 2013b) can be linked to changes in the aspectual system of English.

Massam (1990: 179):

"The result of the cognate object construction-forming lexical subordination process is the creation of a transitional verb or the spell-out of the transitional aspect of the verb."

Roberge (2002):

"It could very well be therefore that a Cognate Object be used to check an aspectual feature of the clause."

Hence, we would like to examine the hypothesis of a correlation between the above changes in cognate arguments in the history of English and an innovation in the aspectual system, in particular the development of the progressive aspect in English. To test our hypothesis that the grammaticalization of the progressive plays a role in the development of cognate arguments, we will first examine the chronology of the development of the progressive in English.

We assume that the progressive aspect derives from the Old English construction $B E$ $+V$-ende. ${ }^{30}$ According to van Gelderen (2004: 203ff), the progressive is a Middle English innovation, used only after 1400, and its use increased especially in the 19th and 20th centuries (see also below for a relevant corpus study and analysis). This change has been analyzed

${ }^{30}$ In the present paper, we do not discuss the details of other possible sources and processes that have been proposed for the progressive in English. For example, there are several analyses of the grammaticalization of the progressive in English that consider that it developed out of a PP + nominal construction). For more on the diachrony of Aspect (in relation to transitivity), see Lavidas (2013b). 
by van Gelderen as a reanalysis from inner (lexical aspect/aktionsart) to outer aspect (grammatical aspect). The verbal prefixes determine the inner aspect in Old English; as these prefixes disappeared, -ing became considered as the imperfective. Van Gelderen has further shown that by the time of Jane Austen's early 19th century novels Emma, Persuasion, and Pride and Prejudice, the use of the progressive was modern-like (the simple present is used for the habitual aspect whereas the progressive is used for intervals; ex. 28). Van Gelderen locates the first shift (from inner to outer aspect) at the end of the ME period, whereas she locates the shift to the fixed pattern of obligatory -ing in the 19th century.

At this moment ... Mr Elton is shewing your picture ... (Emma I, ch. 7; from van Gelderen 2004)

In Figure 2, we present the results of a corpus study regarding the presence of forms in -end(e/an) and -ing(-yng(e)) coded as markers for the progressive. ${ }^{31}$ We have used the same electronic historical corpora (as in the previous corpora studies): YCOE, PPCME2, PPCEME, PPCMBE. According to a Pearson chi-square test, the results for the development of -ing (vs. -ende) as a progressive marker are statistically significant for the comparisons between M1 and M2 $\left(\chi^{2}=61.81, p<.001\right.$, with an effect size of $\varphi=.56$, which is a large size effect $)$ and between $\mathrm{M} 2$ and M3 $\left(\chi^{2}=56, p<.001\right.$, with an effect size of $\varphi=.53$, which is a large size effect $){ }^{32}$

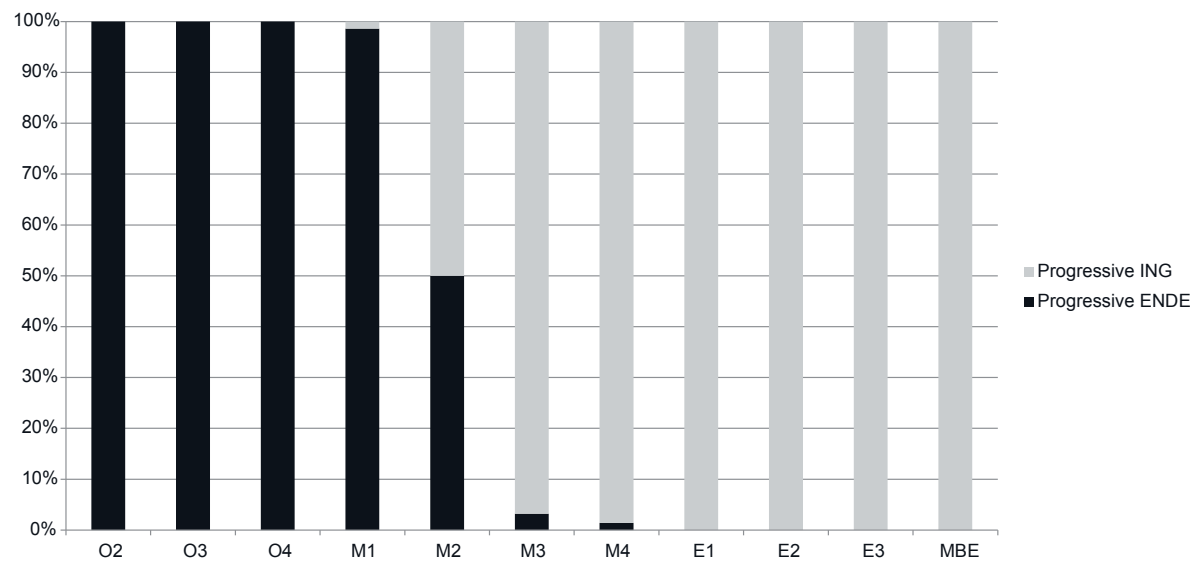

Figure 2: The development of the progressive aspect: -ENDE vs. -ING ${ }^{33}$

31 For more on the theoretical approach and analysis of the interaction between Aspect and cognate arguments, see Lavidas (2013a).

32 Please note that we do not examine the general replacement of the form -ende by the form -ing in Figure 2. We attempt to compare the expression of the progressive by -ende vs. by -ing, and for this purpose, we have counted only the instances where these forms are coded as progressive markers in the electronic historical corpora. The exact function of the be+-ende construction in Old and Early Middle English has not yet been established; we follow the relevant literature that considers -ende as the source for the later progressive -ing in order to present the data as the frequency at which the progressive marked with -ing emerges and evolves vs. those cases in which the alternative (forms with -ende) occurs. Of course, we are aware of the debate on the sources and processes that have been proposed for the progressive in English (see fn. 30) and of the alternative analyses of the rise of progressive in the Early Modern English period (among others, Kranich 2010, Killie 2008).

${ }_{33}$ All data are presented as the frequency at which the phenomenon occurs (for example, progressive marked with -ende) vs. those cases in which the alternative (for example, progressive marked with -ing) occurs (and are analyzed using statistical tests) in an attempt to come to conclusions despite the different sample sizes or any other type of variation among the chronological periods. 
If we compare the data in Figure 2 with that in Tables 2 and 3 in section 3.1, it appears that the results for both the development of -ing (vs. -ende) as a progressive marker and the new cognate constructions are statistically significant for the comparisons between M1 and M2 ${ }^{34}$ and between M2 and M3. ${ }^{35}$ It seems that the results agree with the discussion of the development of the progressive aspect in the relevant literature and that cognate arguments progress in parallel with the development of the progressive aspect. The periods M2 and M3 are the most significant periods for the changes in both cognate objects and the progressive aspect: the cognate objects become common after the M2 and M3 period (see above), whereas the progressive is a Middle English innovation, used only after 1400 (for the progressive, see van Gelderen (2004: 203ff)). On the other hand, the 19th and 20th centuries are crucial for the development both of the cognate subjects and of the progressive aspect again. These centuries are the period of the rise of cognate subjects (see above) as a productive option to be used instead of null subjects in cases of impersonal verbs (for instance, weather verbs). The use of the progressive aspect increases and becomes modern-like in the 19th and 20th century (van Gelderen (2004: $203 \mathrm{ff})$ ).

Conversely, null objects and subjects do not appear to follow cognate objects and subjects in the correlation between cognate arguments and the progressive aspect. Thus, Horrocks and Stavrou's analysis (see also section 1) appears to be supported by the development of the cognate arguments. According to Horrocks and Stavrou (2010: 308), "Modern English allows verbs to be listed with a default aspectual character, which, in the absence of distinct perfective/imperfective stems, can be adjusted by 'aspectual' cognate objects." Old English has no "aspectual" cognate objects because the default aspectual character of verbs seems to be a later development for English, in parallel with the development of the progressive aspect in English. Furthermore, cognate subjects become more common in English during the 19th and 20th centuries because they seem to be affected by the second, more recent, change that concerns the progressive aspect, i.e., the development toward a fixed pattern of obligatory -ing in the 19th century.

\section{Conclusion}

Taking as a starting point the changes in cognate objects and subjects in English - the rise of "aspectual" cognate objects and of expletive cognate subjects with weather verbs - we examined some hypotheses that derive from the relationship of cognate arguments to TR (and EPP and its modifications according to the Minimalist Program). Cognate arguments have followed different paths of development than null arguments, whereas a relationship of both cognate objects and subjects to changes in the aspectual system of English cannot be excluded. Hence, cognate arguments cannot be analyzed as a replacement mechanism for null arguments, but can be linked to the various stages of the development of Aspect in English.

34 For the development of -ing: $p<.001$, with an effect size of $\varphi=.56$, which is a large size effect; for the development of new cognate constructions: $p<.001$, with an effect size of $\varphi=.25$, which is a medium size effect.

${ }^{35}$ For the development of -ing: $p<.001$, with an effect size of $\varphi=.53$, which is a large size effect; for the development of the "die + death" cognate construction: $p=.01$, with an effect size of $\varphi=.06$, which is a small size effect. 


\section{References}

Aarts, Bas 1995. Secondary predicates in English. In Aarts, Bas \& Meyer, Charles F. (eds.), The verb in contemporary English: Theory and description, 75-100. Cambridge: Cambridge University Press.

Alexiadou, Artemis \& Anagnostopoulou, Elena. 1998. Parametrizing agr: Word order, verb-movement and EPPchecking. Natural Language and Linguistic Theory 16(3). 491-539.

Allerton, D.J. 2002. Stretched verb constructions in English. London-New York: Routledge.

Basilico, David. 1998. Object position and predication forms. Natural Language and Linguistic Theory 16. 541-595.

Borer, Hagit. 1994. The projection of arguments. In Benedicto, Elena \& Runner, Jeffrey (eds.), Functional projections. University of Massachusetts Occasional Papers 17, 19-46. Amherst: University of Massachusetts, GLSA.

Bowers, John. 2002. Transitivity. Linguistic Inquiry 33. 183-224.

Cummins, Sarah \& Roberge, Yves. 2004. Null objects in French and English. In: Auger, Julie \& Clements, Clancy \& Vance, Barbara (eds.), Contemporary approaches to Romance linguistics: Selected papers from the 33rd Linguistic Symposium on Romance Languages (LSRL), 121-138. Amsterdam-Philadelphia: John Benjamins.

Cummins, Sarah \& Roberge, Yves. 2005. A modular account of null objects in French. Syntax 8(1). 44-64.

Denison, David. 1993. English historical syntax: Verbal constructions. London-New York: Longman.

DOE: Dictionary of Old English: A to G on CD-ROM. Cameron, Angus et al. (eds.). Toronto: Pontifical Institute of Mediaeval Studies for the Dictionary of Old English Project 2008.

Erteschik-Shir, Nomi \& Rapoport, Tova R. 2004. Bare aspect: A theory of syntactic projection. In Guéron, Jacqueline \& Lecarme, Jacqueline (eds.), The syntax of time, 217-234. Cambridge, Mass.: MIT Press.

Frascarelli, Mara \& Hinterhölzl, Roland. 2007. Types of topics in German and Italian. In Schwabe, Kerstin \& Winkler, Susanne (eds.), On Information Structure, Meaning and Form, 87-116. Amsterdam \& Philadelphia: John Benjamins.

García Velasco, Daniel \& Portero Muñoz, Carmen. 2002. Understood objects in functional grammar (Working Papers in Functional Grammar 76). University of Amsterdam.

Gelderen van, Elly. 2000a. A history of English reflexive pronouns: Person, self, and interpretability. AmsterdamPhiladelphia: John Benjamins.

Gelderen van, Elly. 2000b. The role of person in the loss of verbal agreement and of pro-drop. In Fischer, Olga \& Stein Dieter (eds.), Pathways of change: Grammaticalization processes in Older English, 187-206. Berlin: Mouton de Gruyter.

Gelderen van, Elly. 2004. Grammaticalization as economy. Amsterdam-Philadelphia: John Benjamins.

Gelderen van, Elly. 2010. "Pro-drop and pronominal subjects: Reanalyzing features in the history of English. Paper presented at the Workshop "Subjects in Diachrony", Regensburg. http://www.public.asu.edu/ gelderen/ Regensburg-talk.pdf.

Giannakidou, Anastasia \& Merchant, Jason. 1997. On the interpretation of null indefinite objects in Greek. Studies in Greek Linguistics 17. 141-155.

Gummere, Francis B. (ed.). 1910. Beowulf (The Harvard Classics 49). New York: P.F. Collier \& Son.

Höche, Silke. 2009. Cognate object constructions in English. A cognitive-linguistic account. Tübingen: Narr.

Horrocks, Geoffrey \& Stavrou, Melita. 2003. Actions and their results in Greek and English: The complementarity of morphologically encoded (viewpoint) aspect and syntactic resultative predication. Journal of Semantics 20. 297-327.

Horrocks, Geoffrey \& Stavrou, Melita. 2007. Grammaticalized Aspect and Spatio-temporal Culmination. Lingua 117. 605-644.

Horrocks, Geoffrey \& Stavrou Melita. 2010. Morphological aspect and the distribution of cognate objects across languages. In Rappaport Hovav, Malka \& Doron, Edit \& Sichel, Ivy (eds.), Lexical semantics, syntax, and event structure, 284-308. Oxford: Oxford University Press.

Huang, James C.-T. 1984. On the distribution and reference of empty pronouns. Linguistic Inquiry 15. 531-574. Jones, Michael Allen. 1988. Cognate objects and the case filter. Journal of Linguistics 24. 89-111.

Killie, Kristin. 2008. From locative to durative to focalized? The English progressive and 'PROG imperfective drift'. In Gotti, Maurizio \& Dossena, Marina \& Dury, Richard (eds.), English historical linguistics 2006. Vol. 1: Syntax and morphology, 69-88. Amsterdam-Philadelphia: John Benjamins. 
Kranich, Svenja. 2010. The progressive in Modern English. A corpus-based study of grammaticalization and related changes. Amsterdam-New York: Rodopi.

Kroch, Anthony. 1989. Reflexes of grammar in patterns of language change. Language Variation and Change 1. 199-244.

Kroch, Anthony \& Taylor Ann. 2000. The Penn-Helsinki Parsed Corpus of Middle English (PPCME2). Department of Linguistics, University of Pennsylvania. CD-ROM, second edition. http://www.ling.upenn.edu/histcorpora.

Kroch, Anthony \& Santorini, Beatrice \& Delfs, Lauren. 2004. The Penn-Helsinki Parsed Corpus of Early Modern English (PPCEME). Department of Linguistics, University of Pennsylvania. CD-ROM, first edition. http://www.ling.upenn.edu/hist-corpora.

Kroch, Anthony \& Santorini, Beatrice \& Diertani, Ariel. 2010. The Penn-Helsinki Parsed Corpus of Modern British English (PPCMBE). Department of Linguistics, University of Pennsylvania. CD-ROM, first edition. http://www.ling.upenn.edu/hist-corpora.

Lambrecht, Knud \& Lemoine, Kevin. 1996. Vers une grammaire des compléments zéro en français parlé. In Chuquet, Jean \& Fryd, Mare (eds.), Travaux linguistiques du CERLICO 9. Absence de marques et représentation de l'absence, 279-306. Rennes: Presses universitaires de Rennes.

Larjavaara, Meri. 2000. Présence ou absence de l'objet. Limites du possible en français contemporain. Helsinki: Academia Scientiarum Fennica.

Larson, Richard. 1988. On the double object construction. Linguistic Inquiry 19. 335-391.

Lavidas, Nikolaos. 2013a. Unaccusativity and the diachrony of null and cognate objects in Greek. In Gelderen van, Elly \& Barðdal, Jóhanna \& Cennamo, Michela (eds.). 2012. Argument Structure in Flux: The NaplesCapri Papers. Amsterdam-Philadelphia: John Benjamins.

Lavidas, Nikolaos. 2013b. Null and cognate objects and changes in (in)transitivity: Evidence from the history of English. Acta Linguistica Hungarica 60(1). 69-106.

Los, Bettelou \& Kemenade, Ans van. 2012. Discourse and information structure in the history of English. In Bergs, Alexander \& Brinton, Laurel (eds.), Historical Linguistics of English (HSK 34.2), 1475-1490. Berlin: Mouton de Gruyter.

Macfarland, Talke. 1995. Cognate objects and the argument/adjunct distinction in English. Northwestern University. (Ph.D. dissertation)

Massam, Diane. 1990. Cognate objects as thematic objects. Canadian Journal of Linguistics 35. 161-190.

MED: Middle English Dictionary, XXII vol. 1956-1999. Kurath, Hans \& Kuhn, Sherman M. (eds.). Ann Arbor: University of Michigan Press. http://ets.umdl.umich.edu/m/mec.

Mittwoch, Anita. 1998. Cognate objects as reflections of Davidsonian event arguments. In Rothstein, Susan (ed.), 309-332. Events and Grammar. Dordrecht: Kluwer.

Nevalainen, Terttu \& Raumolin-Brunberg, Helena \& Keränen, Jukka \& Nevala, Minna \& Nurmi, Arja \& Palander-Collin, Minna. 1998. Corpus of Early English Correspondence (CEEC). Department of English, University of Helsinki. http://www. helsinki.fi/varieng/CoRD/corpora/CEEC.

OED: The Oxford English Dictionary [Online]. Simpson, John A. (ed.). Oxford: Oxford University Press. http:// www.oed.com.

Panagiotidis, Phoevos. 2003. Empty nouns. Natural Language and Linguistic Theory 21. 381-432.

Pereltsvaig, Asya. 1999. Two classes of cognate objects. In: Shahin, Kimary \& Blake, Susan \& Kim, Eun-Sook (eds.), The Proceedings of the WCCFL XVII, 537-551. Stanford: CSLI Publications.

Pintzuk, Susan. 2002. Morphological case and word order in Old English. Language Sciences 24. 381-395.

Pirvulescu, Mihaela \& Roberge, Yves. 1999. Objects and the structure of imperatives. In: Authier, J.-Marc \& Bullock, Barbara E. \& Reed, Lisa A. (eds.), Formal perspectives on Romance linguistics, 211-226. Amsterdam-Philadelphia: John Benjamins.

Roberge, Yves. 2002. Transitivity requirement effects and the EPP. Paper presented at the Western Conference on Linguistics (WECOL), November 2002, Vancouver.

Sigurðsson, Halldór Ármann. 2007. Argument features, clausal structure and the computation. In Reuland, Eric \& Bhattacharya, Tanmoy \& Spathas, Giorgos (eds.), Argument Structure, 121-158. Amsterdam-Philadelphia: John Benjamins.

Sigurðsson, Halldór Ármann. 2011. Conditions on argument drop. Linguistic Inquiry 42. 267-304.

Taylor, Ann \& Warner, Anthony \& Pintzuk, Susan \& Beths, Frank. 2003. The York-Toronto-Helsinki Parsed Corpus of Old English Prose (YCOE). Department of Language and Linguistic Science, University of York. Available through the Oxford Text Archive. 
Tenny, Carol. 1987. Grammaticalizing Aspect and Affectedness. MIT. (Ph.D. dissertation)

Tenny, Carol. 1994. Aspectual roles and the syntax-semantics interface. Dordrecht: Kluwer.

Travis, Lisa. 1994. Event phrase and a theory of functional categories. In Koskinen, Paivi (ed.), Proceedings of the 1994 Canadian Linguistic Association Meeting at the University of Calgary, 559-570. Toronto: Toronto Working Papers in Linguistics.

Tsimpli, Ianthi Maria \& Papadopoulou, Despina. 2006. Aspect and argument realization: A study on antecedentless null objects in Greek. Lingua 116. 1595-1615.

Visser, Frederikus Theodorus (1963) [2002]. An historical syntax of the English language. Vol. 1. Leiden: E.J. Brill.

Walkden, George. 2011. Null arguments in Old English. Paper presented at the LAGB 2011. http://www.srcf. ucam.org/ gw249/Walkden 2011 LAGB.pdf.

Williams, Alexander. 2000. Null subjects in Middle English existentials. In Pintzuk, Susan \& Tsoulas, George \& Warner, Anthony (eds.), Diachronic syntax: Models and mechanisms, 164-188. Oxford: Oxford University Press.

Zaefferer, Dietmar. 2002. The puzzle of the autoantonymous argument role. Unraveling the polysemy of risk/ riskieren. In Restle, David \& Zaefferer, Dietmar (eds.), Festschrift for Theo Vennemann on the occasion of his 65th birthday, 413-437. Berlin: Mouton de Gruyter. 